D

$\star$
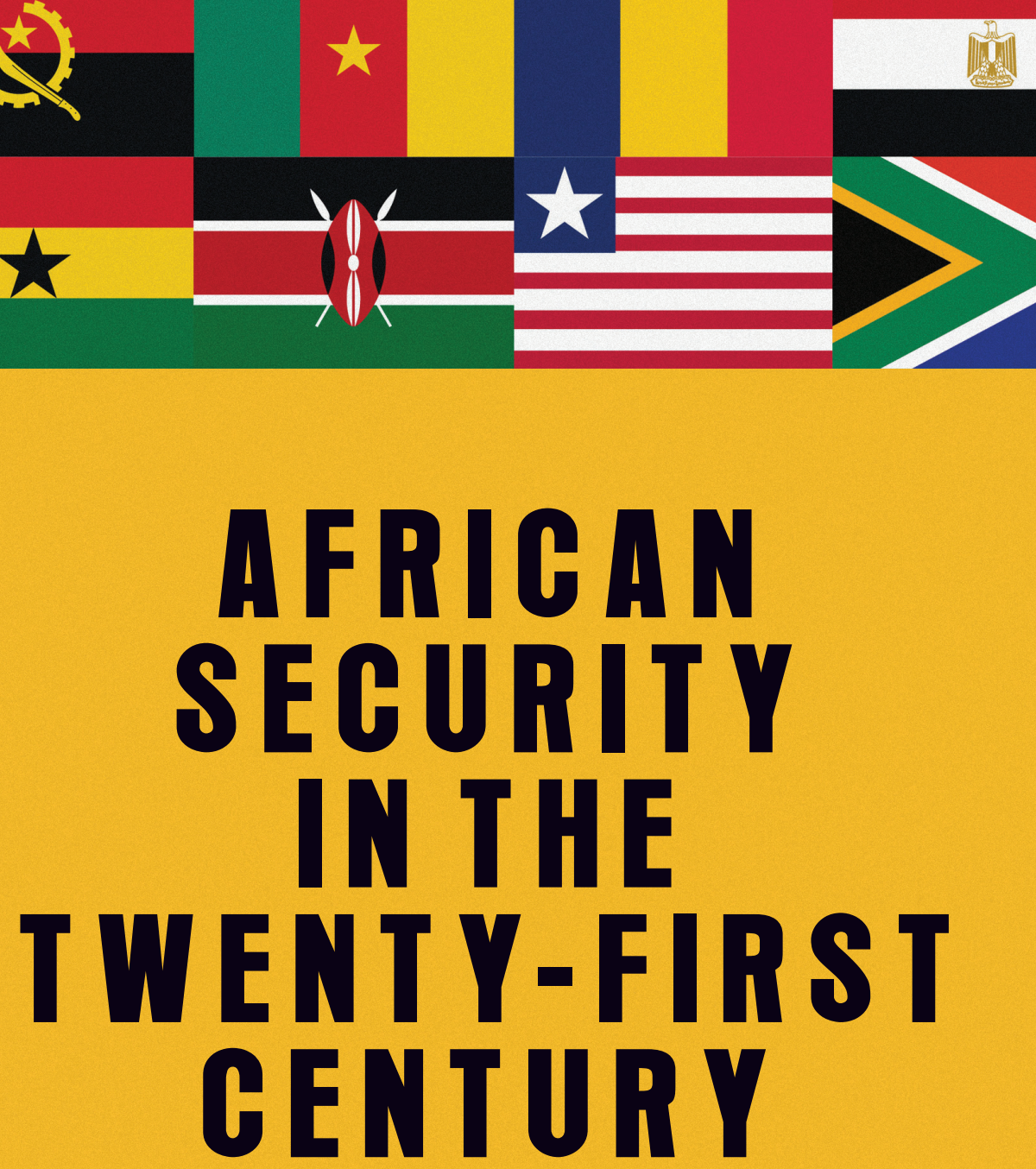

CHALLENGES AND OPPORTUNITIES

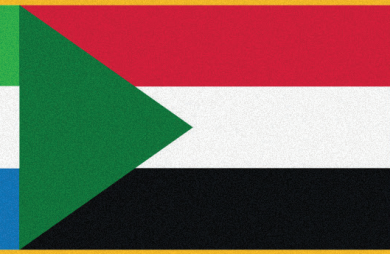

STEPHEN EMERSON HUSSEIN SOLOMON 


\section{African security in the twenty-first century}

\section{MANCHESTER 1824}

Manchester University Press 
Stephen Emerson and Hussein Solomon - 9781526122742 Downloaded from manchesterhive.com at 04/26/2023 03:53: 05AM 


\section{African security in the twenty-first century \\ Challenges and opportunities}

\section{STEPHEN EMERSON AND HUSSEIN SOLOMON}

Manchester University Press 
The right of Stephen Emerson and Hussein Solomon to be identified as the authors of this work has been asserted by them in accordance with the Copyright, Designs and Patents Act 1988.

Published by Manchester University Press

Altrincham Street, Manchester M1 7JA

www.manchesteruniversitypress.co.uk

British Library Cataloguing-in-Publication Data

A catalogue record for this book is available from the British Library

ISBN 9781526122735 hardback

First published 2018

The publisher has no responsibility for the persistence or accuracy of URLs for any external or third-party internet websites referred to in this book, and does not guarantee that any content on such websites is, or will remain, accurate or appropriate.

Typeset in Sabon and Gill by

Servis Filmsetting Ltd, Stockport, Cheshire 